\title{
Artisanal mining impacts small mammals while chainsaw milling is a more sustainable practice in Ghana
}

\author{
Eric Adjei Lawer ${ }^{1,2}$ (D) Anne-Christine Mupepele ${ }^{1,3}$ (D) $\cdot$ Alexandra-Maria Klein ${ }^{1}$ (D)
}

Received: 4 May 2020 / Revised: 11 November 2020 / Accepted: 18 November 2020 /

Published online: 2 December 2020

(C) The Author(s) 2020

\begin{abstract}
Logging and mining are widespread in most West African countries and considering their socio-economic importance, little is known about their ecological impacts. In this study, we investigated the effects of chainsaw milling (logging) and artisanal mining on terrestrial small mammal communities in a tropical forest in Ghana. For this, we compared abundance, diversity measures and community composition of small mammals active at the forest floor in logged, mined and undisturbed forest sites. We found that abundance was higher in logged and undisturbed forest sites than in mined sites. Small mammal species richness, Shannon diversity and Pielou's evenness did not differ significantly among the three forest disturbance categories. Community composition of small mammals varied between mined and undisturbed sites as well as between mined and logged sites, suggesting differential species responses to altered environments. This may be due to the presence of pits in mined forest sites, hence a reduction in exploitable ground habitat structures for shelter, nesting or food. Overall, our results suggest that artisanal mining has strong impacts on community composition of forest floor small mammals in tropical forests while the effect of logging by chainsaw milling activities is minimal, especially when practiced at low intensity. This effect was moderated by elevation and distance to streams that equally shaped small mammal communities. More research on the effects of specific forms of logging and mining activities on small mammals are urgently needed to better protect species in forests impacted by logging and mining.
\end{abstract}

Keywords Atewa forest · Forest disturbance $\cdot$ Logging $\cdot$ Mining

Communicated by Karen E. Hodges.

Electronic supplementary material The online version of this article (https://doi.org/10.1007/s10531-02002089-0) contains supplementary material, which is available to authorized users.

Eric Adjei Lawer

ladjei@uds.edu.gh

1 Nature Conservation and Landscape Ecology, University of Freiburg, Tennenbacherstr. 4, 79106 Freiburg, Germany

2 Biodiversity Conservation and Management, University for Development Studies, Tamale, Ghana

3 Senckenberg Biodiversity and Climate Research Center, Frankfurt, Germany 


\section{Introduction}

Biodiversity in tropical forests is increasingly threatened by forest degradation despite the efforts to curb deforestation (Malhi et al. 2014; Climate Focus 2015). In West Africa, about $14 \%$ of the total land area is covered with forests, many of them being biodiversity hotspots (FAO 2003). Forests are threatened by several anthropogenic pressures such as logging and mining (Jones et al. 2018). This has resulted in an annual forest loss of about 1.2 million hectares in West Africa since 1990 (FAO 2003). In Ghana, the average annual deforestation within protected forest reserves was estimated at $0.6 \%$ between 1990 and 2015 (Acheampong et al. 2019). Lack of economic opportunities and ineffective environmental policies have been highlighted as the drivers of deforestation especially where human population is rapidly increasing (Geist and Lambin 2002) and the majority of the local human population depends on forests for their livelihoods (Appiah et al. 2009; Hussain et al. 2019).

Chainsaw milling is a specific form of logging or timber processing that involves the selective removal of single or small groups of mature trees and their on-site conversion to lumber. It is a major livelihood sustenance activity in forests of West Africa. Societal demand for processed timber often compels people to adopt this method since investment costs are low compared to conventional large-scale logging and lumbering methods such as clearcutting. The socio-economic importance of the chainsaw milling sector to rural and urban livelihoods (e.g. via employment) and national economies (e.g. via taxes) has been widely documented compared to its ecological impacts (Marfo 2010; Obiri and Damnyag 2011; Lescuyer et al. 2016). The activity of chainsaw milling often generates more residue (i.e. coarse woody debris) composed of slabs and billets compared to conventional logging (Asamoah et al. 2011) thus, enhancing the micro-habitat of many vertebrate species including small mammals (Bull 2002; Davis et al. 2010).

Mining for marketable mineral resources such as gold and bauxite is another important economic activity improving the livelihoods of people and occurs widely in some countries of West Africa. Mining activities differ in their scale (i.e. large or small) and can be distinguished by the degree of mechanization and compliance with global industrial standards (Hentschel et al. 2003). Artisanal and small-scale mining is a general term referring to the use of low-tech, labor-intensive methods for mineral processing and extraction (Hilson and Pardie 2006). In Ghana, the activity often involves the manual removal of vegetation and soil (usually 3-12 m deep and not more than $2.4 \mathrm{~m}$ wide) to recover precious minerals using simple tools such as pick-axes, cutlasses, chisels and shovels (Botchway 1995). The activity adds new structures (e.g. pits/ditches) to the environment thus, structurally modifying it and eventually resulting in habitat loss or creation of new habitats for some organisms such as aquatic macro-invertebrates (Steele and Grant 1982; Larkin et al. 2008; Bylak et al. 2019).

Other environmental or habitat variables such as elevation, canopy cover and riparian areas have been shown to influence the distribution and diversity of organisms (Richardson et al. 2000; Adila et al. 2017). For instance, wildlife species richness in relation to elevation often follows a hump-shaped pattern peaking at intermediate levels (Andrade and Monjeau 2014; Flores et al. 2018). Also, forest canopy cover is positively correlated with wildlife species richness implying that undisturbed forest sites will support more communities than disturbed sites due to loss of cover/habitat (Subasinghe et al. 2014; Whitworth et al. 2019). Similarly, riparian areas constitute significant wildlife habitats for aquatic organisms as well as support terrestrial food webs via energy exports: i.e. aquatic 
insects are preyed on when they emerge (Kauffman et al. 2001). The diversity and density of organisms often decreases with increasing distance away from water bodies (Thrash et al. 1995; Adila et al. 2017). However, human activities such as logging and mining (i.e. placer/alluvial) can dramatically alter some of these variables (Mertens et al. 2001; Jarsjö et al. 2017) with potential ramifications for biodiversity conservation due to habitat loss (Alroy 2017; Horváth et al. 2019).

Our study seeks to shed light on the impacts of these two widespread livelihood activities on forest floor small mammals in a tropical forest in Ghana. Small mammals are mammals that typically weigh less than $5 \mathrm{~kg}$, such as shrews and rodents. They are an important component of the Guinean forest ecosystem of West Africa. They can influence vegetation structure through seed predation and dispersal and serve as food for other organisms including humans (Sieg 1987; Gruber 2016). The abundance of small mammals and their diversity were shown to decline in areas with conventional logging (Simard and Fryxell 2003; Bogdziewicz and Zwolak 2014) and large-scale mining (Ardente et al. 2016; Attuquayefio et al. 2017), potentially threatening the integrity of forest ecosystems (Parrish et al. 2003). Yet, the impact of artisanal and small-scale mining and chainsaw milling on small mammals is still poorly understood. We hypothesize that species abundance, diversity and community composition of small mammals using the forest floor will differ between logged, mined and undisturbed forest sites due to differences in habitat structure. Given that artisanal and small-scale mining negatively affects the horizontal habitat structure (i.e. presence of pits) thereby limiting movement and exploitable surface area for food while chainsaw milling may enhance it (i.e. coarse woody debris), we expect that composition of small mammals using the forest floor will be most impacted by mining activities. We further investigate whether other environmental factors such as elevation, canopy cover and proximity of sites to water sources (i.e. stream/river) can explain changes in community composition of small mammals.

\section{Methods}

\section{Study area}

The study was conducted in Atewa, an upland evergreen forest and biodiversity hotspot located within the high forest zone of Ghana (Fig. 1). The mountain range is characterized by plateaus which run in a north to south orientation peaking at $842 \mathrm{~m}$ above sea level (Hall and Swaine 1981). Atewa is comprised of two forest blocks namely Atewa range $\left(237 \mathrm{~km}^{2}\right)$ and Atewa range extension $\left(21.3 \mathrm{~km}^{2}\right)$. Our study occurred in the larger forest block, Atewa range forest reserve. The forest has a bimodal rainfall pattern with an average annual precipitation of about $1650 \mathrm{~mm}$. Major and minor wet seasons occur from May to July and September to October/November respectively. It has a network of streams with the headwaters of three major rivers (Ayensu, Birim and Densu) originating from the reserve. The forest is biologically diverse in flora and fauna with several rare and endemic species, such as the Atewa dotted butterfly (Mylothris atewa), the Colobus monkey (Colobus vellerosus) and the large-headed shrew (Crocidura grandiceps) (McCullough et al. 2007). Fourteen non-volant small mammal species (e.g. rodents, shrews) have so far been confirmed for the reserve with two of them being threatened (e.g. C. grandiceps and C. wimmeri) (Weber and Fahr 2007; Lindsell et al. 2019).

Aside from its rich biodiversity, portions of the reserve have significant gold and bauxite deposits drawing the interests of international mining companies as well as 

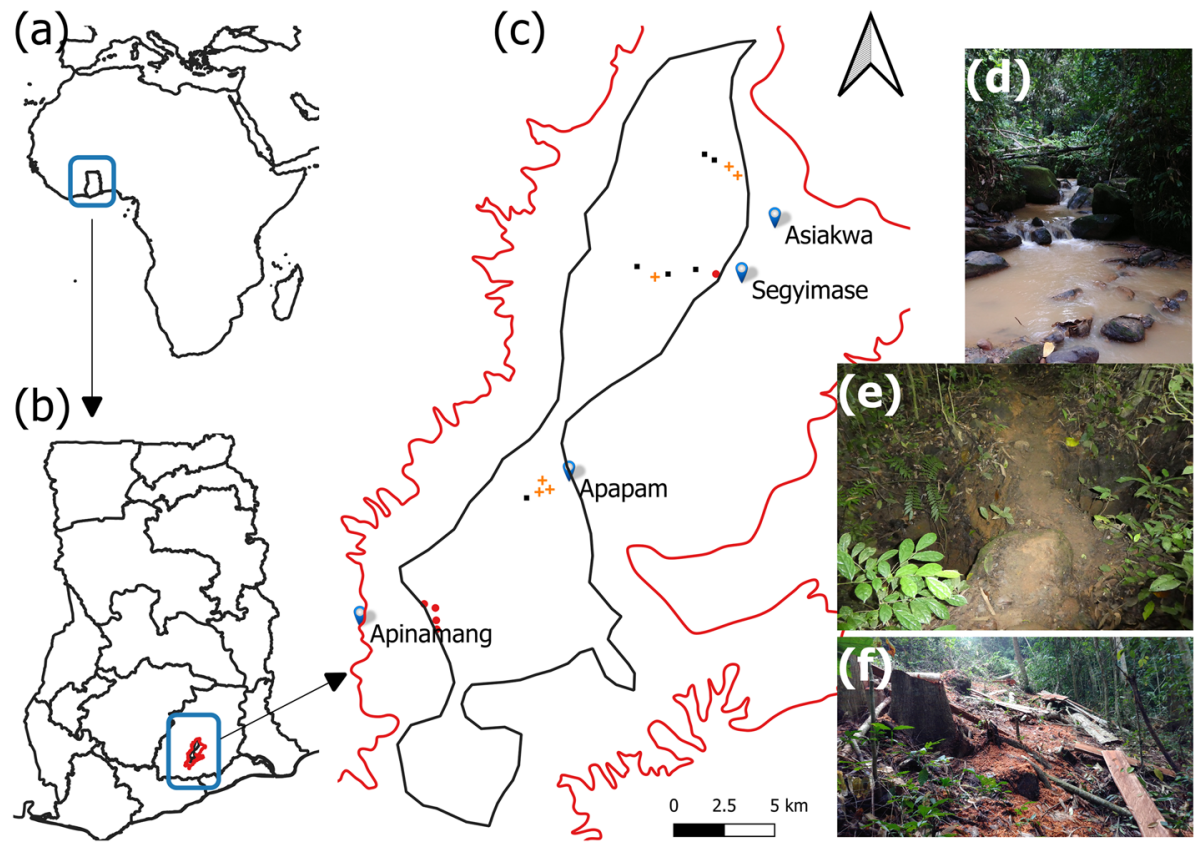

Fig. 1 Map of Africa (a) showing the study country Ghana (b) and the sampled sites in Atewa forest reserve (c). The red outline in 'c' shows the Atewa mountain range while the black outline represents the forest reserve. Logged sites are denoted by orange crosses, mined sites by red filled circles and undisturbed sites by black filled squares. From d-f polluted stream from artisanal mining; mined site showing pits dug manually with pick axes and shovels; logged site showing tree stump, slabs and billet

individuals interested in artisanal and small-scale mining. Logging (i.e. chainsaw milling) also occurs widely in the reserve. These activities can be notoriously patchy due to the spatial distribution of mineral deposits and commercial timber species. Exploitation of these resources are often higher in sites with greater concentrations of mineral deposits and high value marketable trees. Due to anthropogenic activities such as illegal farming, logging and mining, the forest reserve is becoming a mosaic of disturbed and undisturbed forest sites (Kusimi 2015).

\section{Site selection}

We sampled small mammals in logged, mined and undisturbed forest sites within Atewa range forest reserve (Fig. 1). Sites were chosen based on the absence or presence of logging (here chainsaw milling) and mining (here artisanal mining) disturbance within the forest and were separated by an average distance of $821 \mathrm{~m}(\min =596 \mathrm{~m}, \max =1367 \mathrm{~m})$. Because some small mammal species have large dispersal distances or home range sizes (Jones et al. 2009; Whitmee and Orme 2013), our investigation was more analogous to habitat use patterns than long-term occupancy which assumes population closure and sample independence (MacKenzie et al. 2002). The former could also be used to investigate habitat effects on species distribution and abundance (Boyce et al. 2016).

Investigated mined sites had 4-15 pits site ${ }^{-1}$ while logged sites had logging intensities of 2-7 trees site $^{-1}$ (i.e. $0.68 \pm 0.21$ ha). Artisanal mining may or may not occur 
concomitantly with logging, but in most cases it occurs under the forest canopy to reduce chances of aerial detection. We ensured that chosen sites did not accumulate both disturbance or degradation effects at the time of investigation. Neither of these activities used heavy machinery such as skidders, loaders or excavators in the sites investigated. Because these activities are predominant in certain communities (especially artisanal mining), we purposively selected these localities for our investigation: Apinamang, Asiakwa, Kibi Apapam and Segyimase. Unlike chainsaw milling, artisanal mining can occur at a place for a long period of time with individuals creating small camps in the area. We therefore selected more mined sites at Apinamang since the activity is widespread there with more abandoned mined sites. We sampled 14 sites (5 logged, 4 mined, 5 undisturbed) in the first trapping session (i.e. wet season: July 01-August 05, 2018) and increased it to 17 (6 logged, 5 mined, 6 undisturbed) in the second session (i.e. dry season: November 08December 19, 2018). Elevation, canopy cover, and distance of site to stream/river were measured at each site to test for the effect of these variables on small mammal communities (Supplementary Material, Appendix S1). Elevation and distance measurements were made using a handheld GPS device while canopy cover was measured via an ocular estimation approach (Kent 2012). Due to the illegality of logging and mining activities in the reserve, it was difficult to obtain information on the history of disturbance. We observed occasionally that previously logged or abandoned mined sites showed signs of recent human activity.

\section{Live-trapping and animal handling}

A total of 30 traps arranged in a $5 \times 5$ array of sampling points and separated by a distance of $10 \mathrm{~m}$ were placed at each site for the live capture of small mammals. Tomahawk traps $(48.26 \mathrm{~cm} \times 15.24 \mathrm{~cm} \times 15.24 \mathrm{~cm})$ were placed at the four outer corners and the center of the array while Sherman traps $(7.62 \mathrm{~cm} \times 8.89 \mathrm{~cm} \times 22.86 \mathrm{~cm})$ were placed at all intermediate knots (Appendix S2). Traps at each site/grid were active for three consecutive nights per sampling session with arrays left unchanged during trapping sessions. This resulted in a sampling effort of 1260 trap nights in the wet season and 1530 trap nights in the dry season. All traps were placed at ground level preferably at places that provided cover for small mammals (e.g. downed wood and rocks) and baited with peanut butter mixed with oat, corn and dried fish. The traps were set before sunset on the first day and checked daily between 6 and 9am for captures. Animals captured for the first time were marked using ear tags with unique codes to allow for identification of recaptures (National Band and Tag Company, USA). Recaptured individuals were counted only once for all statistical analyses. Individuals were identified to the species level using identification guides (Grubb et al. 1998; Kingdon et al. 2013; Monadjem et al. 2015) and assigned to a dietary guild (Kissling et al. 2014).

\section{Data analysis}

We calculated three different measures of diversity (richness, Shannon-Wiener diversity index and Pielou's evenness Pielou 1966; Magurran 2004)) and tested for differences between logged, mined and undisturbed forest study sites using Kruskal-Wallis test (Shapiro Wilk normality test, $\mathrm{p}<0.05$ ) (Sokal and Rohlf 1995). Abundance data for each species was also subjected to Kruskal-Wallis analysis of variance to examine variation in abundance among forest disturbance categories. Dunn's test with 'fdr' Benjamini- 
Hochberg adjustment for multiple comparisons was applied for pairwise comparison to further discriminate among the different forest disturbance categories when $\mathrm{p}<0.05$ for Kruskal-Wallis tests (Elliott and Hynan 2011). To examine the effect of disturbance intensity on species abundance and richness, we classified sampled sites into areas of low or high intensity and subjected the data to a Wilcoxon test. Low intensity disturbance sites had 2-4 harvested trees or 4-9 mine pits while high intensity sites had 5-7 harvested trees or $10-15$ mine pits.

We applied non-metric multidimensional scaling (NMDS) to explore how small mammal communities differed based on taxonomic composition (vegan package, Oksanen et al. 2019). This was done using euclidean distances on Hellinger transformed species abundance data. Environmental variables (i.e. canopy cover, elevation, stream proximity) were then fit onto the ordination to identify how they can explain the shape of the plots (function 'envfit'). Additionally, effects of the forest disturbance categories, canopy cover, elevation and distance to stream were analyzed using permutational multivariate analysis of variance (PERMANOVA) (function 'adonis'). If significant differences occurred, a PERMANOVA pairwise comparison with Bonferroni correction was applied as a post-hoc test. We pooled species abundance data from both seasons for all analyses (except disturbance intensity analysis) because overall and species-specific abundances did not differ by season ( $p>0.05)$. All analyses were performed in the program R (R Core Team 2020).

\section{Results}

\section{Abundance and diversity measures of small mammals}

During the course of the investigation, we trapped a total of 98 unique individuals from 6 species with a sampling effort of 2790 trap nights (Table 1). This represented about $43 \%$ of the small mammal species that have been documented for the reserve (Lindsell et al. 2019). Rarefaction curves also indicate that more species are present in the forest (Appendix S3). Five species were recorded in logged compared to four in both mined and undisturbed forest study sites (Fig. 2). Sampled species comprised of different dietary guilds with mined forest study sites consisting of only omnivores (Table 1: insectivores, herbivores and omnivores). Two species (Lophuromys sikapusi [rusty-bellied brush-furred rat] and Lemniscomys striatus [typical striped grass mouse]) found in logged sites were not found in

Table 1 Species abundance, dietary guilds and IUCN Red List status ( $L C$ least concern, $N T$ near threatened) in the different forest disturbance sites

\begin{tabular}{llllll}
\hline \multirow{2}{*}{ Species } & \multicolumn{2}{l}{ Forest disturbance (abundance) } & & Foraging guild & \multirow{2}{*}{ Red List status } \\
\cline { 2 - 5 } & Mined & Logged & Undisturbed & & \\
\hline Malacomys edwardsi & 1 & 22 & 30 & Omnivore & LC \\
Praomys tullbergi & 3 & 13 & 8 & Omnivore & LC \\
Cricetomys emini & 5 & 1 & 4 & Omnivore & LC \\
Lophuromys sikapusi & 3 & 4 & 0 & Omnivore & LC \\
Lemniscomys striatus & 0 & 3 & 0 & Herbivore & LC \\
Crocidura grandiceps & 0 & 0 & 1 & Insectivore & NT \\
\hline
\end{tabular}




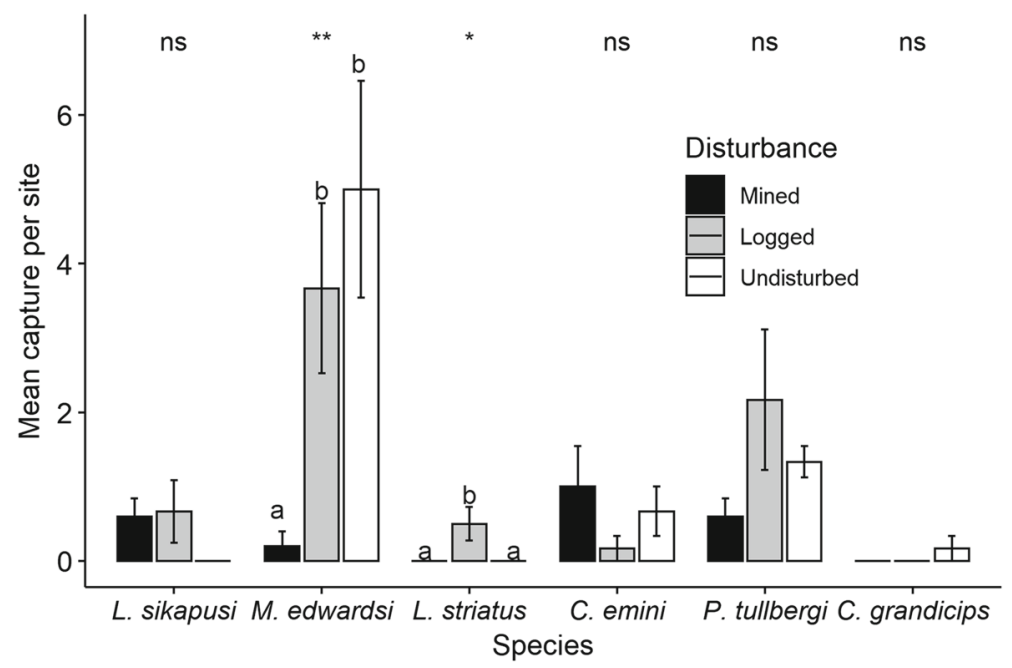

Fig. 2 Mean abundance per site of captured species in the different forest disturbance categories. Each species was analyzed independently using non-parametric Kruskal-Wallis test. Letters indicate statistical differences based on Dunn's correction test (displayed for only significant parameters) and error bars represent the standard error $(\mathrm{SE})$. Significant $(* \mathrm{p}<0.05, * * \mathrm{p}<0.01)$ and non-significant disturbance category comparisons for each species is denoted by 'stars' and 'ns' respectively

undisturbed forest study sites (rusty-bellied brush-furred rat was however found in mined sites). Crocidura grandiceps (large-headed shrew) which is considered to be near threatened by the IUCN was only captured in undisturbed forest sites (Table 1). The two most abundant species captured were Malacomys edwardsi (Edward's swamp rat) and Praomys tullbergi (Tullberg's soft-furred mouse), occurring primarily in logged and undisturbed forest study sites (Fig. 2; Table 1). Mean abundance of Edward's swamp rat for example, was significantly lower in mined compared to logged and undisturbed forest study sites. Species richness was similar in logged, mined and undisturbed forest study sites (KruskalWallis test: $\mathrm{df}=2, \mathrm{KW}=0.458, \mathrm{p}=0.795$, Fig. 3a). Diversity and evenness were generally high in logged but did not significantly differ from mined and undisturbed forest study sites (Fig. 3b, c). We found no differences between low and high intensity disturbance areas for logged and mined sites based on abundance and species richness (Fig. 4). Additionally, the relationship between disturbance intensity (i.e. standardized scores) and abundance was weak and negative $(\mathrm{r}=-0.191, \mathrm{p}=0.421)$ (Appendix S4).

\section{Community composition of small mammal under logging and mining}

Small mammal composition at the forest floor differed significantly between the forest disturbance categories (PERMANOVA: $\mathrm{df}=2, \mathrm{~F}=4.913, \mathrm{p}=<0.001$; Fig. 5, Appendix S5). Post-hoc tests revealed that while undisturbed and logged study sites did not differ in the composition of small mammals $(\mathrm{F}=1.742, \mathrm{p}=0.576)$, they both differed from mined study sites in the composition of species (undisturbed vs. mined $-\mathrm{F}=9.346, \mathrm{p}=0.018$; logged vs. mined $-\mathrm{F}=4.473, \mathrm{p}=0.030$ ). Patterns of community composition were related to elevation $\left(r^{2}=0.453, p=0.020\right)$ and site proximity to streams $\left(r^{2}=0.436\right.$, $\mathrm{p}=0.023$, Fig. 6, Appendix S6) indicating that composition in study sites at higher elevations were different from sites at lower elevations. Also, sites closer to streams differed 
Fig. 3 Plot of species richness (a), Shannon-Wiener diversity index (b), and Pielou's evenness (c) per site. p-values are based on a non-parametric Kruskal-Wallis test. Rarefaction curves are provided in Appendix S3
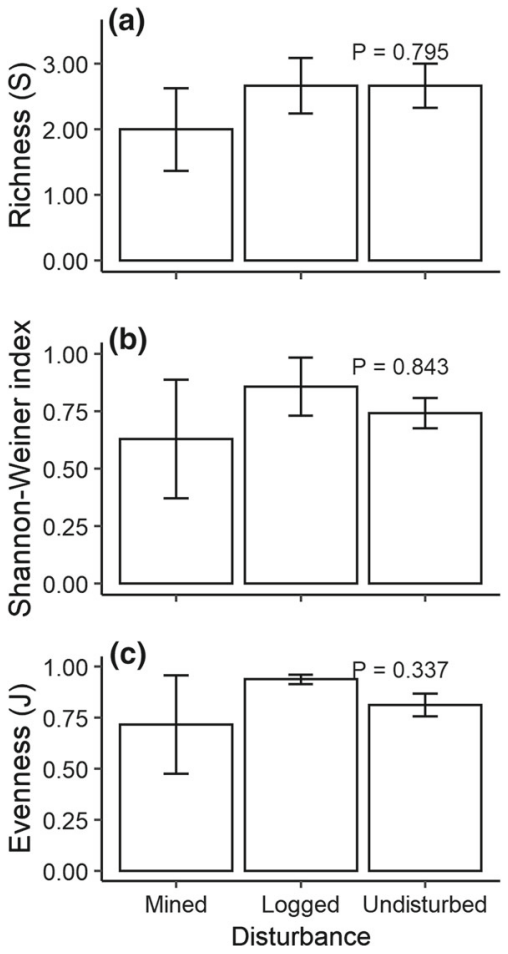

in composition from sites farther away from streams. For example, species in undisturbed sites such as Edward's swamp rat were associated with higher elevation levels and were in close proximity to streams while the typical striped grass mouse occurred at intermediate to lower elevations, was found farther from streams and was generally more abundant in the logged forest sites (Fig. 6).

\section{Discussion}

As chainsaw milling, artisanal mining and other anthropogenic disturbance pressures continue to increase within tropical forests, it becomes vital to understand how species and communities react to different habitat disturbances mediated by humans for appropriate conservation and management interventions. We therefore examined the effects of logging (chainsaw milling) and mining (artisanal mining) on forest floor small mammals using live trapping protocols established at multiple locations. Our results showed that: (a) mean abundance of certain species (e.g. Edward's swamp rat) was significantly higher in logged and undisturbed forest sites compared to mined forest sites; (b) mean richness, diversity and evenness were lower in mined forest sites but did not differ significantly across logged, mined and undisturbed forest sites; (c) mining may potentially alter the community composition of small mammals and; (d) elevation and site distance to streams appear to be correlated with community composition of small mammals.

Habitat disturbances can facilitate the invasion of more generalized small mammal species (Mazerolle et al. 2001). Two species, rusty-bellied brush-furred rat and typical striped grass mouse were captured only in disturbed forest sites (logged and mined) and 
Fig. 4 Effect of disturbance intensity on abundance (a) and species richness of small mammals (b)
Fig. 5 Non-metric

multidimensional scaling plot of small mammal composition based on data from all trapping sessions $(\mathrm{K}=3$, Stress $=0.013)$ (a)

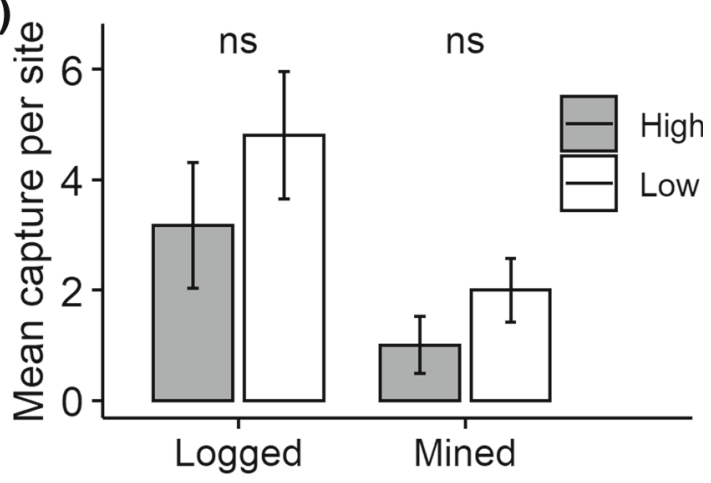

(b)
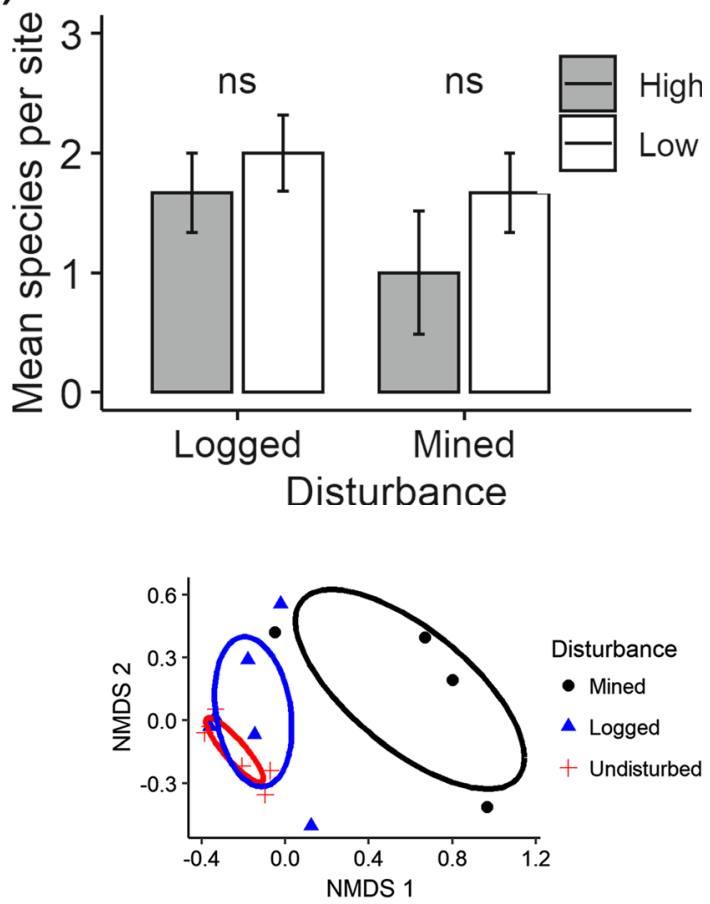

they are both known to be habitat generalists, i.e. able to cope with disturbed forests and other habitat types (Hutterer et al. 1992; Weber and Fahr 2007). The large-headed shrew, on the other hand, is a forest specialist captured in undisturbed sites and is considered to be threatened according to the IUCN Red List status (Hutterer 2008). Forest sites with mining had lower species abundance and diversity compared to undisturbed forest sites, but the difference was not significant as in other studies (Ardente et al. 2016; Attuquayefio et al. 2017).

Differences in dietary guild composition observed across the different disturbance categories in forests, provide initial indications that omnivores may cope well under disturbance pressures. Vulnerability of some dietary guilds may explain the varying 
Fig. 6 Non-metric

multidimensional scaling plot of small mammal composition (i.e. species are displayed on plots) with response surfaces fitted for significantly correlated variables: a site elevation $(\mathrm{m})$ and $\mathbf{b}$ site distance from streams $(\mathrm{m})$

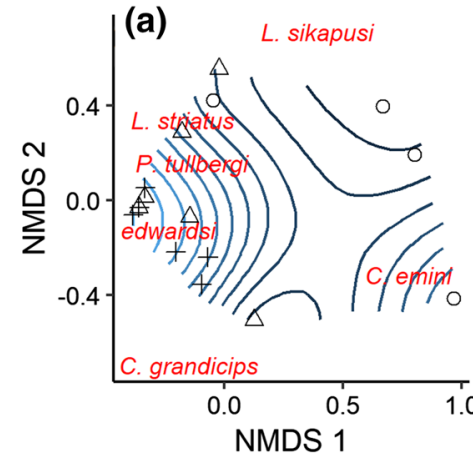

Elevation (m)

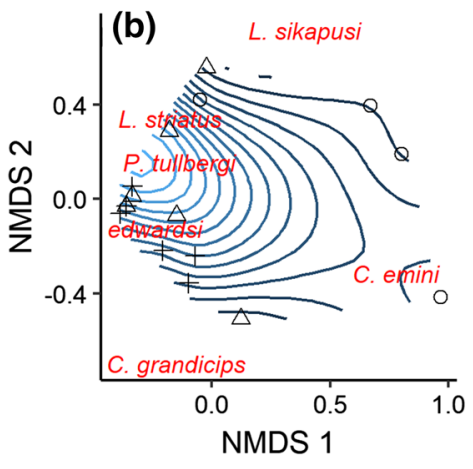

\section{Disturbance}

$\triangle$ Logged

- Mined

+ Undisturbed

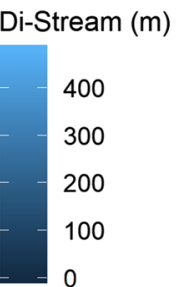

functional group compositions observed in human-altered forest sites (Luke et al. 2014; Maure et al. 2018). Given that most species in our study were omnivores and there was only one insectivore (large-headed shrew) and one herbivore species (typical striped grass mouse), no general statement about these two more specialized dietary guilds can be made.

Unlike other studies, we found no significant relationship between disturbance intensity and species abundance or richness, most likely because disturbance intensity was rather similar across sites, differing only in the number of pits and logged trees (Carreño-Rocabado et al. 2012; Burivalova et al. 2014). Older sites may show faster signs of passive recovery in terms of both flora and fauna than newly disturbed sites of the same size (Meli et al. 2017; Lawer et al. 2019). The disturbance history of our sites is unknown and cannot be reconstructed due to the activities being illegal, but we assume that our replicated sampling design could randomly capture a variety of different disturbance histories and therefore seems unlikely to bias our results. Future studies may additionally incorporate disturbance age and eventually confirm our results with even stronger effects additionally mediated by disturbance age.

Community composition of small mammals differed between the disturbance categories being especially different in mined forest sites. Pits in mined sites reduce the surface area that small mammals using the forest floor can use for shelter or nesting (and limit movement) (Sasaki et al. 2015; Cristescu et al. 2016). Thus, the very low relative abundance per species recorded in mined sites could have influenced the variation in community composition observed. The most commonly captured species, Edward's swamp rat and Tullberg's soft-furred mouse were of similar proportions in both logged and undisturbed forest sites. Because the forest is still connected, there might be movement of 
animals between sites thus, the lack of compositional differences between logged and undisturbed forest sites (Sverdrup-Thygeson et al. 2017). We suppose that wood residue generated from chainsaw milling operations (e.g. slab, billet, rejected beams) could have constituted coarse woody debris thus, likely influencing the presence and abundance of Edward's swamp rat, a forest dwelling species and other small mammals in logged forest sites. Our arguments are supported by studies that have demonstrated the positive relationship between coarse woody debris and small mammal communities (Loeb 1999; Sullivan et al. 2012; Craig et al. 2014; Seip et al. 2018). Further, as chainsaw milling involves selective removal of single or few trees, the activity tends to mimic natural canopy openings (e.g. tree fall) to which small mammals are probably adapted to and hence we do not find differences in community composition between logged and undisturbed forest sites (Wells et al. 2007).

We found that elevation and proximity of sites to streams were correlated with community composition of small mammals. However, an alternative test (Permanova) did not reveal a significant impact of these factors on community composition, indicating that these conclusions may be less robust if based on our study only. Elevational gradients have been shown to be related to soil properties (He et al. 2016; Badía et al. 2016) which in turn affect the distribution and composition of plants and invertebrates (Jing et al. 2005; Junker and Larue-Kontić 2018), thus influencing food and shelter resources required by small mammals. The non-linear relationship between small mammal composition and elevation likely suggests differential species responses as well as potential vulnerabilities in the presence of anthropogenic pressures (Flores et al. 2018). Furthermore, the uniqueness and intrinsic value of riparian zones make them important wildlife habitats as they influence species distribution and terrestrial food webs (Kauffman et al. 2001; Anthony et al. 2003). For example, the emergence of aquatic invertebrates or insects export energy to terrestrial systems in the form of food for riparian predators (Sanzone et al. 2003; Gratton and Vander Zanden 2009; Dreyer et al. 2015). Also, high plant cover or vegetation in riparian areas serve as food sources and may provide protection from predators hence, influencing community composition (Hamilton et al. 2015). Thus, the patterns of community composition observed likely reflect the changes in occurrence and abundance of species over elevational as well as across aquatic-terrestrial gradients.

\section{Management and conservation implications}

With this study we could show that forest disturbance by logging and mining affect forest floor small mammal communities, presumably through changes in the presence and abundance of species. Whereas mining could potentially change the composition of forest floor small mammals, the effects from logging appeared to be minimal. Beside human disturbance, other environmental factors related to the micro-habitat may influence small mammal communities (Roberts et al. 1978; Stancampiano and Schnell 2004). In our study, elevation and proximity of sites to streams/rivers influenced community composition of small mammals.

There is strong evidence that human disturbance activities affect habitat use patterns of animals (Béchet et al. 2004; Howey et al. 2016; Cruz et al. 2018). Small mammal persistence may be impeded with increasing habitat fragmentation or decreasing connectivity due to their limited dispersal ability (Bailey et al. 2010; Braaker et al. 2014; SverdrupThygeson et al. 2017). Presently, our findings suggest the possible use of logged sites from chainsaw milling by small mammals as refuge for shelter or food among others. 
The current trend of economic development in the country will continue to stimulate the growth of both the artisanal and small-scale mining and chainsaw milling sectors with potential ramifications for biodiversity due to deforestation or habitat loss. Our study has shown that chainsaw milling can be sustainable with minor to no impact on small mammals, whereas artisanal and small-scale mining needs to be observed and regulated more carefully having stronger impacts on the small mammal community.

Acknowledgements Thanks to Esther Darkoh, Dominic Danso, Caleb Anim, Clinton Boateng, Solomon Teye, Francis Teye and other members of the field team for their assistance in field work. Thanks also goes to Dr. Jan Decher for his initial comments and advice before field work in Ghana.

Author contributions EAL conceived the research idea; EAL, ACM and AMK designed the methodology; EAL collected field data, performed all statistical analyses and led the writing of the manuscript. ACM helped with statistical advice, edited and improved the manuscript together with AMK. The final version of the manuscript was read and approved by all authors.

Funding Open Access funding enabled and organized by Projekt DEAL. Financial support was provided by the German Academic Exchange Service (DAAD) and the Ghanaian government (i.e. Ministry of Education) for EAL's PhD study in Germany. ACM was funded by the STAY scholarship of the Neue Universitätsstiftung Freiburg, Germany.

Data availability Raw data is available in the electronic supplementary material.

\section{Compliance with ethical standards}

Conflict of interest The authors declare that they have no conflict of interest.

Ethical approval All procedures followed the guidelines of the American Society of Mammalogists for the use of wild mammals in research. Also, captures were in accordance with the relevant Ghanaian laws following permission granted by the Forestry Commission (G494/97).

Open Access This article is licensed under a Creative Commons Attribution 4.0 International License, which permits use, sharing, adaptation, distribution and reproduction in any medium or format, as long as you give appropriate credit to the original author(s) and the source, provide a link to the Creative Commons licence, and indicate if changes were made. The images or other third party material in this article are included in the article's Creative Commons licence, unless indicated otherwise in a credit line to the material. If material is not included in the article's Creative Commons licence and your intended use is not permitted by statutory regulation or exceeds the permitted use, you will need to obtain permission directly from the copyright holder. To view a copy of this licence, visit http://creativecommons.org/licenses/by/4.0/.

\section{References}

Acheampong EO, Macgregor CJ, Sloan S, Sayer J (2019) Deforestation is driven by agricultural expansion in Ghana's forest reserves. Sci Afr 5:e00146. https://doi.org/10.1016/j.sciaf.2019.e00146

Adila N, Sasidhran S, Kamarudin N et al (2017) Effects of peat swamp logging and agricultural expansion on species richness of native mammals in Peninsular Malaysia. Basic Appl Ecol 22:1-10. https://doi. org/10.1016/J.BAAE.2017.04.002

Alroy J (2017) Effects of habitat disturbance on tropical forest biodiversity. Proc Natl Acad Sci 114:6056-6061. https://doi.org/10.1073/pnas.1611855114

Andrade A, Monjeau A (2014) Patterns in community assemblage and species richness of small mammals across an altitudinal gradient in semi-arid Patagonia, Argentina. J Arid Environ 106:18-26. https://doi. org/10.1016/J.JARIDENV.2014.02.004

Anthony RG, O'Connell M, Pollock M, Hallett J (2003) Associations of mammals with riparian ecosystems in Pacific Northwest forest. In: Zabel C, Anthony RG (eds) Mammal community dynamics: 
management and conservation in the coniferous forests of Western North America. Cambridge University Press, Cambridge, pp 510-563

Appiah M, Blay D, Damnyag L et al (2009) Dependence on forest resources and tropical deforestation in Ghana. Environ Dev Sustain 11:471-487. https://doi.org/10.1007/s10668-007-9125-0

Ardente NC, Ferreguetti ÁC, Gettinger D et al (2016) Diversity and impacts of mining on the non-volant small mammal communities of two vegetation types in the Brazilian Amazon. PLoS ONE 11:1-16. https://doi.org/10.1371/journal.pone.0167266

Asamoah KA, Duah-Gyamfi A, Dabo J (2011) Ecological impacts of uncontrolled chainsaw milling on natural forests. Ghana J For 27:12-23

Attuquayefio DK, Owusu EH, Ofori BY (2017) Impact of mining and forest regeneration on small mammal biodiversity in the Western Region of Ghana. Environ Monit Assess 189:237. https://doi.org/10.1007/ s10661-017-5960-0

Badía D, Ruiz A, Girona A et al (2016) The influence of elevation on soil properties and forest litter in the Siliceous Moncayo Massif, SW Europe. J Mt Sci 13:2155-2169. https://doi.org/10.1007/s11629-0153773-6

Bailey D, Schmidt-Entling MH, Eberhart P et al (2010) Effects of habitat amount and isolation on biodiversity in fragmented traditional orchards. J Appl Ecol 47:1003-1013. https://doi.org/10.1111/j.13652664.2010.01858.x

Béchet A, Giroux J-F, Gauthier G (2004) The effects of disturbance on behaviour, habitat use and energy of spring staging snow geese. J Appl Ecol 41:689-700

Bogdziewicz M, Zwolak R (2014) Responses of small mammals to clear-cutting in temperate and boreal forests of Europe: a meta-analysis and review. Eur J For Res 133:1-11. https://doi.org/10.1007/s10342013-0726-X

Botchway FNN (1995) Pre-colonial methods of gold mining and environmental protection in Ghana. J Energy Nat Resour Law 13:299-311. https://doi.org/10.1080/02646811.1995.11433041

Boyce MS, Johnson CJ, Merrill EH et al (2016) Can habitat selection predict abundance? J Anim Ecol 85:11-20. https://doi.org/10.1111/1365-2656.12359

Braaker S, Moretti M, Boesch R et al (2014) Assessing habitat connectivity for ground-dwelling animals in an urban environment. Ecol Appl 24:1583-1595. https://doi.org/10.1890/13-1088.1

Bull EL (2002) The value of coarse woody debris to vertebrates in the Pacific Northwest. In: Laudenslayer WFJ, Shea PJ, Valentine BE, et al. (eds) Proceedings of the symposium on the ecology and management of dead wood in western forests. United States Department of Agriculture, Forest Service, General Technical Report PSW-GTR-181, pp 171-178

Burivalova Z, Şekercioğlu ÇH, Koh LP (2014) Thresholds of logging intensity to maintain tropical forest biodiversity. Curr Biol 24:1893-1898. https://doi.org/10.1016/j.cub.2014.06.065

Bylak A, Rak W, Wójcik M et al (2019) Analysis of macrobenthic communities in a post-mining sulphur pit lake (Poland). Mine Water Environ 38:536-550. https://doi.org/10.1007/s10230-019-00624-2

Carreño-Rocabado G, Peña-Claros M, Bongers F et al (2012) Effects of disturbance intensity on species and functional diversity in a tropical forest. J Ecol 100:1453-1463. https://doi.org/10.1111/j.1365-2745. 2012.02015.x

Climate Focus (2015) Progress on the New York declaration on forests - an assessment framework and initial report. Prepared by Climate Focus, in collaboration with Environmental Defense Fund, Forest Trends, The Global Alliance for Clean Cookstoves, and The Global Canopy Program

Craig MD, Grigg AH, Hobbs RJ, Hardy GESJ (2014) Does coarse woody debris density and volume influence the terrestrial vertebrate community in restored bauxite mines? For Ecol Manage 318:142-150. https://doi.org/10.1016/j.foreco.2014.01.011

Cristescu B, Stenhouse GB, Boyce MS (2016) Large omnivore movements in response to surface mining and mine reclamation. Sci Rep 6:19177. https://doi.org/10.1038/srep19177

Cruz P, Iezzi ME, De Angelo C et al (2018) Effects of human impacts on habitat use, activity patterns and ecological relationships among medium and small felids of the Atlantic Forest. PLoS ONE 13:e0200806. https://doi.org/10.1371/journal.pone.0200806

Davis JC, Castleberry SB, Kilgo JC (2010) Influence of coarse woody debris on the soricid community in southeastern Coastal Plain pine stands. J Mammal 91:993-999. https://doi.org/10.1644/09-MAMM-A170.1

Dreyer J, Townsend PA, Hook JC III et al (2015) Quantifying aquatic insect deposition from lake to land. Ecology 96:499-509. https://doi.org/10.1890/14-0704.1

Elliott AC, Hynan LS (2011) A SAS $®$ macro implementation of a multiple comparison post hoc test for a Kruskal-Wallis analysis. Comput Methods Programs Biomed 102:75-80. https://doi.org/10.1016/J. CMPB.2010.11.002

FAO (2003) Forestry outlook study for Africa. Sub regional report-West Africa. FAO, Rome 
Flores O, Seoane J, Hevia V, Azcárate FM (2018) Spatial patterns of species richness and nestedness in ant assemblages along an elevational gradient in a Mediterranean mountain range. PLoS ONE 13:e0204787. https://doi.org/10.1371/journal.pone.0204787

Geist HJ, Lambin EF (2002) Proximate causes and underlying driving forces of tropical deforestation: tropical forests are disappearing as the result of many pressures, both local and regional, acting in various combinations in different geographical locations. Bioscience 52:143-150. https://doi.org/10. 1641/0006-3568(2002)052[0143:pcaudf]2.0.co;2

Gratton C, Vander Zanden MJ (2009) Flux of aquatic insect productivity to land: comparison of lentic and lotic ecosystems. Ecology 90:2689-2699

Grubb P, Jones TS, Davies AG et al (1998) Mammals of Ghana Sierra Leone and the Gambia. Trendrine Press, Cornwall

Gruber K (2016) Rodent meat-a sustainable way to feed the world? Using rodents as food has a long tradition in many parts of the world. EMBO Rep 17:630-633. https://doi.org/10.15252/embr. 201642306

Hall JB, Swaine MD (1981) Distribution and ecology of vascular plants in a tropical rain forest: forest vegetation in Ghana. Springer, Netherlands

Hamilton BT, Roeder BL, Hatch KA et al (2015) Why is small mammal diversity higher in riparian areas than in uplands? J Arid Environ 119:41-50. https://doi.org/10.1016/J.JARIDENV.2015.03.007

He X, Hou E, Liu Y, Wen D (2016) Altitudinal patterns and controls of plant and soil nutrient concentrations and stoichiometry in subtropical China. Sci Rep 6:24261. https://doi.org/10.1038/srep24261

Hentschel T, Hruschka F, Priester M (2003) Artisanal and small-scale mining: challenges and opportunities. IIED and WBCSD, London

Hilson G, Pardie S (2006) Mercury: an agent of poverty in Ghana's small-scale gold-mining sector? Resour Policy 31:106-116. https://doi.org/10.1016/j.resourpol.2006.09.001

Horváth Z, Ptacnik R, Vad CF, Chase JM (2019) Habitat loss over six decades accelerates regional and local biodiversity loss via changing landscape connectance. Ecol Lett 22:1019-1027. https://doi.org/10. 1111/ele. 13260

Howey CAF, Dickinson MB, Roosenburg WM (2016) Effects of a landscape disturbance on the habitat use and behavior of the black racer. Copeia 104:853-863. https://doi.org/10.1643/CE-15-373

Hussain J, Zhou K, Akbar M et al (2019) Dependence of rural livelihoods on forest resources in Naltar Valley, a dry temperate mountainous region, Pakistan. Glob Ecol Conserv 20:e00765. https://doi.org/ 10.1016/j.gecco.2019.e00765

Hutterer R (2008) Crocidura grandiceps. The IUCN Red List of threatened species 2008: version 2019-2013. www.iucnredlist.org. Accessed 11 Mar 2020

Hutterer R, Dieterlen F, Nikolaus G (1992) Small mammals from forest islands of eastern Nigeria and adjacent Cameroon, with systematical and biogeographical notes. Bonn Zool Beitr 43:393-414

Jarsjö J, Chalov SR, Pietroń J et al (2017) Patterns of soil contamination, erosion and river loading of metals in a gold mining region of northern Mongolia. Reg Environ Change 17:1991-2005. https://doi.org/10. 1007/s10113-017-1169-6

Jing S, Solhøy T, Huifu W et al (2005) Differences in soil arthropod communities along a high altitude gradient at Shergyla Mountain, Tibet, China. Arct Antarct Alp Res 37:261-266

Jones KE, Bielby J, Cardillo M et al (2009) PanTHERIA: a species-level database of life history, ecology, and geography of extant and recently extinct mammals. Ecology 90:2648-2648. https://doi.org/10. 1890/08-1494.1

Jones KR, Venter O, Fuller RA et al (2018) One-third of global protected land is under intense human pressure. Science. https://doi.org/10.1126/science.aap9565

Junker RR, Larue-Kontić A-AC (2018) Elevation predicts the functional composition of alpine plant communities based on vegetative traits, but not based on floral traits. Alp Bot 128:13-22. https://doi. org/10.1007/s00035-017-0198-6

Kauffman J, Mahrt M, Mahrt L, Edge W (2001) Wildlife of riparian habitats. In: Johnson D, O’Neal T (eds) Wildlife-habitat relationships in Oregon and Washington. Oregon State University Press, Corvallis, pp 361-388

Kent M (2012) Vegetation description and data analysis. A practical approach, 2nd edn. Wiley-Blackwell, Chichester

Kingdon J, Happold D, Butynski T et al (2013) Mammals of Africa, vol 6. Bloomsbury Publishing, London

Kissling WD, Dalby L, Fløjgaard C et al (2014) Establishing macroecological trait datasets: digitalization, extrapolation, and validation of diet preferences in terrestrial mammals worldwide. Ecol Evol 4:2913-2930. https://doi.org/10.1002/ece3.1136

Kusimi JM (2015) Characterizing land disturbance in Atewa range forest reserve and buffer zone. Land Use Policy 49:471-482. https://doi.org/10.1016/j.landusepol.2015.08.020 
Larkin JL, Maehr DS, Krupa JJ et al (2008) Small mammal response to vegetation and spoil conditions on a reclaimed surface mine in eastern Kentucky. Southeast Nat 7:401-412. https://doi.org/10.1656/15287092-7.3.401

Lawer EA, Mupepele AC, Klein AM (2019) Responses of small mammals to land restoration after mining. Landsc Ecol 34:473-485. https://doi.org/10.1007/s10980-019-00785-z

Lescuyer G, Cerutti PO, Tsanga R (2016) Contributions of community and individual small-scale logging to sustainable timber management in Cameroon. Int For Rev 18:40-51. https://doi.org/10.1505/ 146554816819683744

Lindsell J, Agyei R, Bosu D, et al (2019) The biodiversity of Atewa forest. Research report. Accra, Ghana

Loeb SC (1999) Responses of small mammals to coarse woody debris in a Southeastern Pine Forest. J Mammal 80:460-471. https://doi.org/10.2307/1383293

Luke SH, Fayle TM, Eggleton P et al (2014) Functional structure of ant and termite assemblages in old growth forest, logged forest and oil palm plantation in Malaysian Borneo. Biodivers Conserv 23:2817-2832. https://doi.org/10.1007/s10531-014-0750-2

MacKenzie DI, Nichols JD, Lachman GB et al (2002) Estimating site occupancy rates when detection probabilities are less than one. Ecology 83:2248-2255. https://doi.org/10.1890/00129658(2002)083[2248:ESORWD]2.0.CO;2

Magurran AE (2004) Measuring biological diversity. Blackwell Pub, Oxford

Malhi Y, Gardner TA, Goldsmith GR et al (2014) Tropical forests in the Anthropocene. Annu Rev Environ Resour 39:125-159. https://doi.org/10.1146/annurev-environ-030713-155141

Marfo E (2010) Chainsaw milling in Ghana: context, drivers and impacts. Tropenbos International, Wageningen

Maure LA, Rodrigues RC, Alcântara ÂV et al (2018) Functional redundancy in bird community decreases with riparian forest width reduction. Ecol Evol 8:10395-10408. https://doi.org/10.1002/ece3.4448

Mazerolle MJ, Drolet B, Desrochers A (2001) Small-mammal responses to peat mining of southeastern Canadian bogs. Can J Zool 79:296-302. https://doi.org/10.1139/cjz-79-2-296

McCullough J, Alonso LE, Naskrecki P et al (2007) A rapid biological assessment of the Atewa Range forest reserve, Eastern Ghana. RAP Bulletin of Biological Assessment 47. Conservation International, Arlington, VA

Meli P, Holl KD, Benayas JMR et al (2017) A global review of past land use, climate, and active vs. passive restoration effects on forest recovery. PLoS ONE 12:e0171368. https://doi.org/10.1371/journal.pone. 0171368

Mertens B, Forni E, Lambin EF (2001) Prediction of the impact of logging activities on forest cover: a casestudy in the East province of Cameroon. J Environ Manage 62:21-36. https://doi.org/10.1006/jema. 2001.0417

Monadjem A, Taylor PJ, Denys C, Cotterill FPD (2015) Rodents of Sub-Saharan Africa. A biogéographic and taxonomic synthesis. De Gruyter, Berlin

Obiri BD, Damnyag L (2011) Socio-economic contribution of illegal chainsaw milling to the Ghanaian rural economy. Ghana J For 27:50-67

Oksanen J, Blanchet FG, Friendly M et al (2019) Vegan: community ecology package. R package version 2.5-6. https://CRAN.R-project.org/package=vegan

Parrish JD, Braun DP, Unnasch RS (2003) Are we conserving what we say we are? Measuring ecological integrity within protected areas. Bioscience 53:851-860. https://doi.org/10.1641/00063568(2003)053[0851:AWCWWS]2.0.CO;2

Pielou EC (1966) The measurement of diversity in different types of biological collections. J Theor Biol 13:131-144. https://doi.org/10.1016/0022-5193(66)90013-0

R Core Team (2020) R: a language and environment for statistical computing. R Core Team, Vienna

Richardson BA, Richardson MJ, Scatena FN, Mcdowell WH (2000) Effects of nutrient availability and other elevational changes on bromeliad populations and their invertebrate communities in a humid tropical forest in Puerto Rico. J Trop Ecol 16:167-188. https://doi.org/10.1017/S0266467400001346

Roberts RD, Johnson MS, Hutton M (1978) Lead contamination of small mammals from abandoned metalliferous mines. Environ Pollut 15:61-69. https://doi.org/10.1016/0013-9327(78)90061-7

Sanzone DM, Meyer JL, Marti E et al (2003) Carbon and nitrogen transfer from a desert stream to riparian predators. Oecologia 134:238-250. https://doi.org/10.1007/s00442-002-1113-3

Sasaki K, Lesbarrères D, Watson G, Litzgus J (2015) Mining-caused changes to habitat structure affect amphibian and reptile population ecology more than metal pollution. Ecol Appl 25:2240-2254. https:// doi.org/10.1890/14-1418.1

Seip CR, Hodder DP, Crowley SM, Johnson CJ (2018) Use of constructed coarse woody debris corridors in a clearcut by American martens (Martes americana) and their prey. For Int J For Res 91:506-513. https://doi.org/10.1093/forestry/cpy010 
Sieg HC (1987) Small mammals: pests or vital components of the ecosystem. In: Uresk DW, Schenbeck GL, Cefkin R (eds) 8th great plains wildlife damage control workshop proceedings, 97; 1987 April 28-30; Rapid City, SD. Gen. Tech. Rep. RM-154. U.S. Department of Agriculture, Forest Service, Rocky Mountain Forest and Range Experiment Station, Fort Collins, CO, pp 88-92

Simard JR, Fryxell JM (2003) Effects of selective logging on terrestrial small mammals and arthropods. Can J Zool 81:1318-1326. https://doi.org/10.1139/z03-129

Sokal RR, Rohlf FJ (1995) Biometry: The principles and practice of statistics in biological research, 3rd edn. W.H. Freeman and Co., New York

Stancampiano AJ, Schnell GD (2004) Microhabitat affinities of small mammals in southwestern Oklahoma. J Mammal 85:948-958. https://doi.org/10.1644/BFW-005

Steele BB, Grant CV (1982) Topographic diversity and islands of natural vegetation: aids in re-establishing bird and mammal communities on reclaimed mines. Reclam Reveg Res 1:367-381

Subasinghe K, Sumanapala AP, Weerawardhena SR (2014) The impact of forest conversion on bird communities in the northern flank of the Knuckles Mountain Forest Range, Sri Lanka. J Asia-Pac Biodivers 7:367-373. https://doi.org/10.1016/j.japb.2014.07.004

Sullivan TP, Sullivan DS, Lindgren PMF, Ransome DB (2012) If we build habitat, will they come? Woody debris structures and conservation of forest mammals. J Mammal 93:1456-1468. https://doi.org/10. 1644/11-MAMM-A-250.1

Sverdrup-Thygeson A, Skarpaas O, Blumentrath S et al (2017) Habitat connectivity affects specialist species richness more than generalists in veteran trees. For Ecol Manage 403:96-102

Thrash I, Theron GK, Bothma JduP (1995) Dry season herbivore densities around drinking troughs in the Kruger National Park. J Arid Environ 29:213-219. https://doi.org/10.1016/S0140-1963(05)80091-6

Weber N, Fahr J (2007) A rapid survey of small mammals from the Atewa Range Forest Reserve, Eastern Region, Ghana. In: McCullough J, Alonso LE, Naskrecki P et al (eds) A rapid biological assessment of the Atewa Range Forest Reserve, Eastern Ghana. RAP Bulletin of Biological Assessment 47. Conservation International, Arlington, pp 90-98

Wells K, Kalko EKV, Lakim MB, Pfeiffer M (2007) Effects of rain forest logging on species richness and assemblage composition of small mammals in Southeast Asia. J Biogeogr 34:1087-1099

Whitmee S, Orme CDL (2013) Predicting dispersal distance in mammals: a trait-based approach. J Anim Ecol 82:211-221. https://doi.org/10.1111/j.1365-2656.2012.02030.x

Whitworth A, Beirne C, Pillco Huarcaya R et al (2019) Human disturbance impacts on rainforest mammals are most notable in the canopy, especially for larger-bodied species. Divers Distrib 25:1166-1178. https://doi.org/10.1111/ddi.12930

Publisher's Note Springer Nature remains neutral with regard to jurisdictional claims in published maps and institutional affiliations. 